\title{
Tool and ideological knowledge in Street Outreach Office working process*
}

\author{
Saberes ideológicos e instrumentais no processo de trabalho no Consultório na Rua \\ Saberes ideológicos e instrumentales en el proceso laboral en el Consultorio en la Calle
}

Maria Terumi Maruyama Kami ${ }^{1}$, Liliana Muller Larocca ${ }^{2}$, Maria Marta Nolasco Chaves ${ }^{2}$, Laura Christina Macedo Piosiadlo², Guilherme Souza Albuquerque $^{3}$

How to cite this article:

Kami MTM, Larocca LM, Chaves MMN, Piosiadlo LCM, Albuquerque GS. Tool and ideological knowledge in Street Outreach Office working process. Rev Esc Enferm USP. 2016;50(3):440-447. DOI: http://dx.doi.org/10.1590/S0080-623420160000400010

\begin{abstract}
* Extracted from the dissertation "Saberes ideológicos e instrumentais dos profissionais que atuam no Consultório na Rua: subsídios para a elaboração de uma funcionalidade no prontuário eletrônico", Graduate Nursing Program, Master's degree, Universidade Federal do Paraná, 2015.

${ }^{1}$ Secretaria Municipal da Saúde de Curitiba, Departamento de Atenção Primária, Curitiba, PR, Brazil.

${ }^{2}$ Universidade Federal do Paraná, Departamento de Enfermagem, Curitiba, PR, Brazil.

${ }^{3}$ Universidade Federal do Paraná, Departamento de Saúde Comunitária, Curitiba, PR, Brazil.
\end{abstract}

\begin{abstract}
Objective: To identify ideological knowledge and tool knowledge that provide support to the Street Outreach Office working process. Method: Qualitative and exploratory research. Twenty Street Outreach Office professionals and six users collected the data, applying different semi-structured interview schedules for each category of participants. The resulting categories were analyzed in light of tool and ideological knowledge presented in the working process. Results: From the participant discourses the following ideological knowledge emerged: public policies and the needs of the person in a street situation and tool knowledge, as well as devices and tools for the care of people in street situations and a weekly schedule. Conclusion: The focus on the working process discourse, supported by ideological knowledge, was verified. The structural dimension of the objective reality of the population in street situations was perceptible in the social determination of being situating on the street. When daily situations were revealed, the limitations to be overcome in the working process context were noticed.
\end{abstract}

\section{DESCRIPTORS}

Homeless Persons; Primary Health Care; Patient Care Team; Health Personnel; Qualitative Research. 


\section{INTRODUCTION}

In Brazil, there is a substantial and increasing number of people in street situations (PSS), with varied lifestyles and relationships with and on the street. This reality implies structural challenges in order to ensure citizenship for this population in the context of social invisibility.

In this multicenter study entitled "National Survey on Populations in Street Situations"(1), conducted in 71 Brazilian cities in the year 2008, it was estimated that 31,922 adults were in this situation. In Curitiba, 2,776 people in street situations were identified ${ }^{(1)}$.

People in street situations have difficulty accessing benefits guaranteed by public policies, including health care resources $^{(2-3)}$. In order to facilitate access to the health care system, the Street Outreach Office (CR - its acronym in Portuguese), in conformity with the guidelines defined by the National Primary Health Care Policy (PNAB - its acronym in Portuguese), was created to serve as the entrance for health care services, providing longitudinal and full attention, coordinating care and health care provision to the population in street situations in loco, or in other points of the health care network ${ }^{(4)}$.

People living on the streets are exposed to risks that require a specific approach from health teams for this population. Since it is an innovative proposal for providing care to people in street situations, the work carried out by the CR team (CRT) shows aspects that were not totally revealed by other authors ${ }^{(5)}$.

The health care working process can be unfolded in terms of purpose, means, tools, and subject, in which two kinds of knowledge are put forward: tool knowledge and ideological knowledge ${ }^{(6)}$.

Therefore, the current study aims to identify the ideological and tool knowledge that subsidizes the Street Outreach Office working process.

This objective is justified because the format of the CRTs is heterogeneous, and because it is necessary to provide visibility to the product that was changed by the action of these agents. Taking into consideration the particularities of the street population, it is fundamental to qualify information management. These are the elements that have led to the following basic question: Which knowledge subsides the Street Outreach Office's working process?

\section{METHOD}

Qualitative and exploratory research was conducted in four CR teams in the city of Curitiba. Twenty CRT professionals registered in the National Health Facility Census and six CR users took part in the study. Selected participants signed an informed consent form (IC).

Regarding the users treated by the CRTs, the inclusion criterion applied were the key informant interview, with the following characteristics: referred by CRT professionals and having received assistance by the CRT within a period of 30 days prior to the interview.

All CRT professionals who were on vacation or on leave during the scheduled period were excluded.
Regarding the key informants, those under 18 years of age, those with signs of legal drug use, and those under the influence of medications or illicit drugs during interview were also excluded.

To maintain the transparency of the data collecting process, aiming at assuring the accuracy, comprehensiveness, and credibility of the study, the consolidated criteria for qualitative research in the health care field proposed by Tong, Sainsbury, and Craig, in an article entitled Consolidated criteria for reporting qualitative research (COREQ): a 32-item checklist for interviews and focus groups $^{(7)}$ were followed.

Data collection was carried out from January to February of 2015, through audio recorded interviews with semi-structured schedules different for each category of participants. The interviews were conducted with leading questions constructed by the author herself.

Regarding the professionals, the purpose was to learn in detail about the typical weekly work at the CR. Therefore, the participants were asked to talk about the facilities and the difficulties they face at work. The interviews were previously scheduled by phone call and lasted 15 to 37 minutes.

The interviews with CR users, characterized as key informants, were carried out through active search, varying from six to 22 minutes in duration. The aim was to identify the situations in which they sought out the CR service, and to verify other issues related to their conditions in terms of living on the streets.

After transcribing and printing the interviews, a new meeting was scheduled with CRT professionals for verification and validation of the transcribed discourses. It was not possible to carry out this step with the users because the researcher was unable to locate them during the period available for data collecting.

After the transcription and validation stages of the interviews, the material was analyzed using the software IRAMUTEQ (Interface de R pour les Analyses Multidimensionnelles de Textes et de Questionnaires). The use of specific software for helping with textual data analysis has becoming increasingly common in Human and Social Sciences qualitative studies ${ }^{(8-9)}$.

Applying the Descending Hierarchical Classification (DHC) allowed a lexicographic analysis of the textual material (corpus), providing contexts (lexical categories) characterized by their terminology and textual segments that share this vocabulary. The corpus-based study (professionals and users) was considered separately.

Data were analyzed according to the theoretical framework adopted for this study (working process) and the categories previously defined: ideological knowledge and tool knowledge.

The research project took into consideration all of the ethical aspects and followed Resolution number 466/2012 from the National Health Council. It was approved by the Research Ethics Committee of the Federal University of Paraná and City Health Office of Curitiba, through opinions number 742.589 and 767.679 . 


\section{RESULTS}

\section{CR PROFESSIONALS}

The corpus of this segment consisted of 20 interviews, which led to four different lexical categories. Analyzing the textual segments of these categories according to the theoretical framework adopted, the ideological knowledge (Chart 1) and the tool knowledge (Chart 2) presented in the working process of the $\mathrm{CR}$ professionals were understood.

Chart 1 - Ideological knowledge evidenced by the discourses of CR professionals - Curitiba, PR, Brazil, 2016

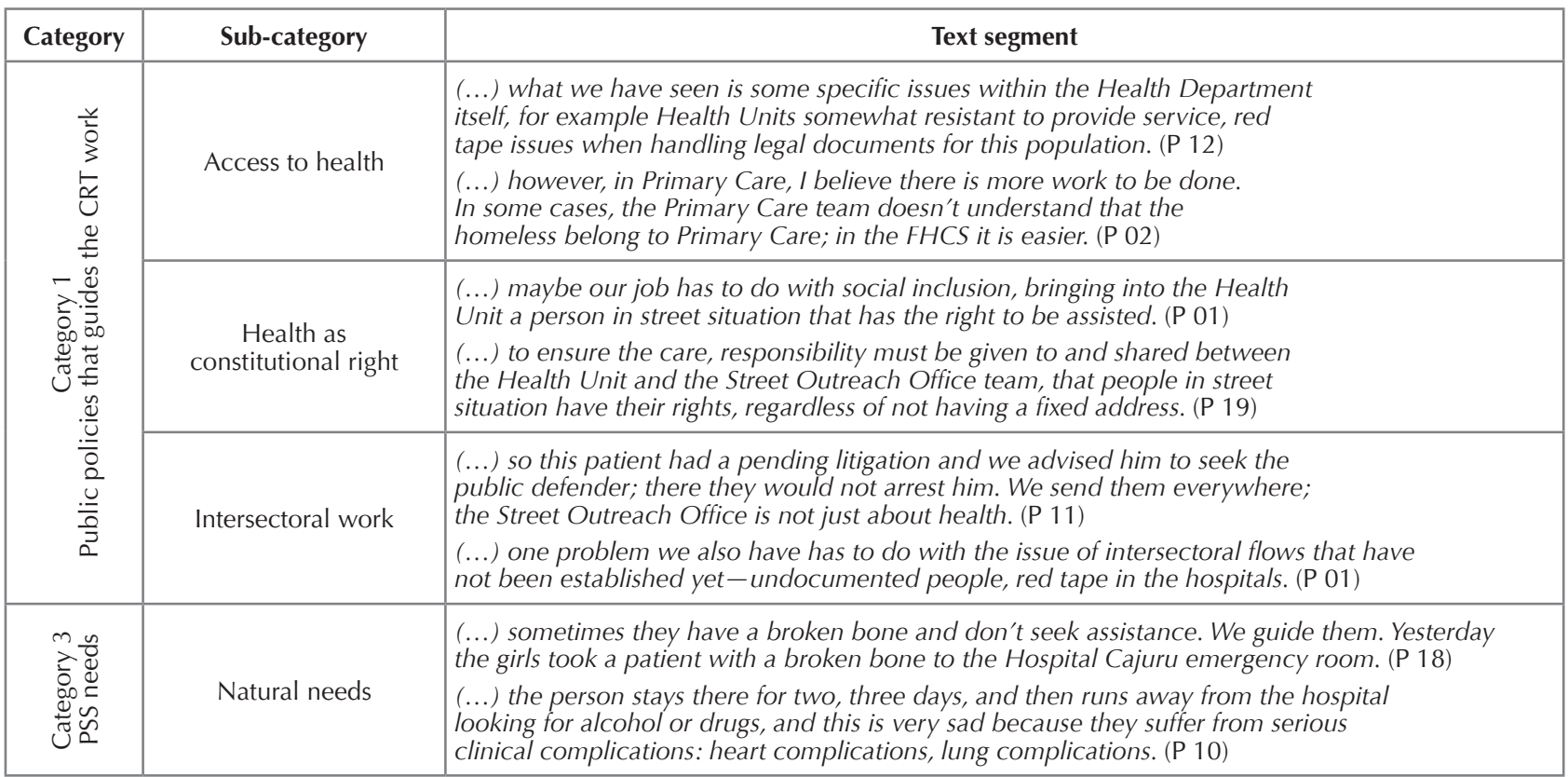

Chart 2 - Tool knowledge evidenced by the discourses of CR professionals - Curitiba, PR, Brazil, 2016

\begin{tabular}{|c|c|c|}
\hline Category & Sub-category & Text segment \\
\hline \multirow{4}{*}{ 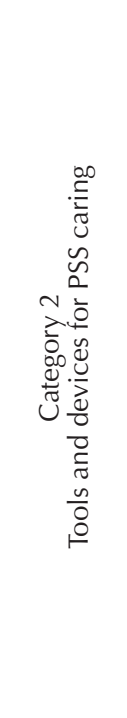 } & Teamwork & $\begin{array}{l}\text { (...) I think the working process is the Street Outreach Office's greatest asset, due to its multi- } \\
\text { professional approach. As a result, according to a given situation, a professional takes more } \\
\text { responsibility than the other; the team has to be tuned up. (P 16) } \\
\text { (...) this means that you can be the best specialist in your area, but in a multidisciplinary scenario } \\
\text { the professional has difficulties sharing the care. (P 19) }\end{array}$ \\
\hline & Relationship & $\begin{array}{l}\text { Several examples were given showing that the relationship is built gradually, but if one word } \\
\text { is expressed untimely by a member of the team, the entire team can end up losing this } \\
\text { relationship. (P 14) } \\
\text { (...) when we get the data from the homeless. We simply don't approach them asking their names } \\
\text { right away, so it takes a lot of time to get the data from this person (...) a lot of time is like this, in } \\
\text { the first meeting, in the second meeting, no one asks "What's your name?", "Good morning! My } \\
\text { name is J., I'm a psychologist and work for the Street Outreach Office. How can I call you?" (P 01) }\end{array}$ \\
\hline & Registration & $\begin{array}{l}\text { We have to go from room to room looking for a place for registering, so we really need a sort of a } \\
\text { mobile unit. (P 04) } \\
\text { (...) the approaches we carry out with patients that we don't have a relationship yet. In other } \\
\text { words, we don't even know the name of the homeless person being assisted and, in order to } \\
\text { register this service, we have to start with the name of the patient first. So our work becomes } \\
\text { invisible. (P 19) }\end{array}$ \\
\hline & Health planning & $\begin{array}{l}\text { (...) we discuss cases that lasted a week, those [where] we had some difficulties. Then we discuss, } \\
\text { gather everyone's opinion, and make a memo. (P 05) }\end{array}$ \\
\hline 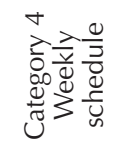 & Weekly schedule & $\begin{array}{l}\text { (...) On Monday afternoon we have a staff meeting for work planning and evaluation. On Monday } \\
\text { morning we visit the same main points. We have a weekly schedule, so on Mondays we actually hit } \\
\text { the streets. (P 17) }\end{array}$ \\
\hline
\end{tabular}

\section{CRT USERS}

The corpus, consisting of six interviews, generated six categories of text segments different from one another. Categories 2, 3, 5, and 6 were not considered, since such segments were not significant in this study because they referred exclusively to the discourse of one user. Categories 1 and 4, according to the typology of needs proposed by Agnes Heller ${ }^{(10)}$, were assigned as ideological knowledge, as presented in Chart 3. 
Chart 3 - Ideological knowledge evidenced in the discourses of CR users - Curitiba, PR, Brazil, 2016

\begin{tabular}{|c|c|}
\hline Category & Text segment \\
\hline \multirow{3}{*}{ 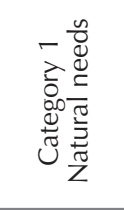 } & $\begin{array}{l}\text { Look, the Street Outreach Office assisted me about three times, only in these last few days. The last time it was } \\
\text { because of a pain in my arm and they took me to Hospital Cajuru. My arm was actually broken. (U 1) }\end{array}$ \\
\hline & $\begin{array}{l}\text { I have been treated two or three times, I'm not sure, but with alcohol issues and dentist, } \\
\text { too (...). The doctor here at the Street Outreach Office referred me to CAPS, (U 4) }\end{array}$ \\
\hline & $\begin{array}{l}\text { I have been treated by the Street Outreach Office several times. They put some bandage on my foot. It was hurting } \\
\text { a lot after a street fight: I tried to protect myself with my foot and something got in the sole of my foot. (U 6) }\end{array}$ \\
\hline \multirow{4}{*}{ 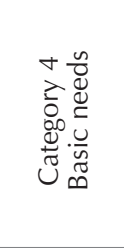 } & $\begin{array}{l}\text { When I was almost winning, I got a kick in my belly and the baby died. They fought } \\
\text { against me. I drink a lot; living on the street is very sad. (U 3) }\end{array}$ \\
\hline & $\begin{array}{l}\text { (...) two weeks that I've been here in the CAPS I was referred by the Street Outreach Office. I got } \\
\text { better, got my mind a bit balanced, in my memory. I want to go back to work. (U 2) }\end{array}$ \\
\hline & $\begin{array}{l}\text { The Street Outreach Office should [have] sent him to another place, because he's willing to sober } \\
\text { up, he has strength for that (...) I'm living on the street since I separated (...), (U 5) }\end{array}$ \\
\hline & (...) I never like studying: I managed to get to the fifth grade only. Then, my mother die[d], and I never got back to school. (U 6) \\
\hline
\end{tabular}

\section{DISCUSSION}

Therefore, it became clear that the circumstances in which the person in a street situation sought out the $\mathrm{CR}$ service were varied, as well as how the issues related to their living on the street conditions were different.

Learning about the reality of the working process in the CRTs, through the discourses of professionals who are part of the teams and from its users, allowed identifying the tools and ideological knowledge presented in the practices these workers undertake. This knowledge is more than converting tools about subject: it is about constructive elements of the working process ${ }^{(6)}$.

The ideological knowledge is based on theoretical health work and legislative principles in themselves, including their agents and products ${ }^{(6)}$, in this study case, professionals working in the CR and the assisted PSS, respectively. Figure 1 shows the tools and ideological knowledge drawn from the discourses.

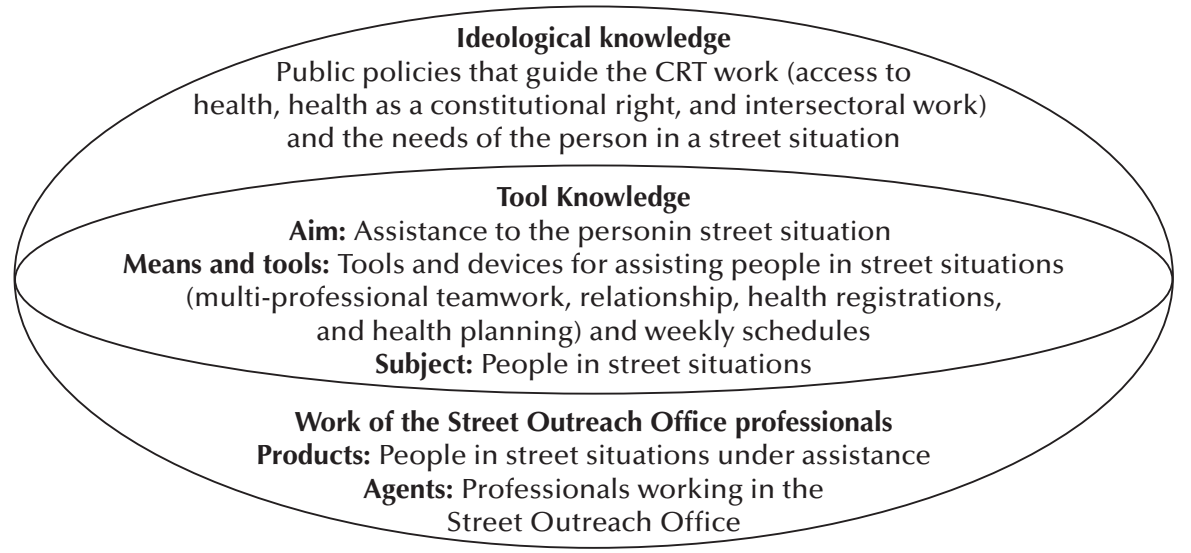

Source: Adapted from Egry ${ }^{(6)}$

Figure 1 - Working process constructive elements of Street Outreach Office professionals, according to the tool and ideological knowledge - Curitiba-PR, 2015.

From the respondents' discourses a tool and ideological knowledge emerged. Their work centrality was particularly aimed at public policies that guide CRT work (access to health, health as a constitutional right, and intersectoral work), as well as the needs of the person in a street situation, which was categorized as ideological knowledge.

This result suggests that the social determination to live on the street was structural, which explains the structural dimension of the objective reality of these workers and users, and these issues not only affect the social structure but become more evident than the organization of the $\mathrm{CR}$ service itself. These findings differ from a study conducted with nurses working in the epidemiology hospital units in a capital located in southern Brazil, in which the centrality of the discourses of the nurses on tool knowledge related to the working process were verified ${ }^{(11)}$.

In the working process of CRT professionals, supported by ideological knowledge, the access to health by the population in street situations was one of the important topics raised by the participants' discourses. Access is one of the Primary Health Care's (PHC) main attributes ${ }^{(12)}$. The creation of the CRT in the surveyed city is in conformity with the National Policy for Population in Street Situations, supported by the National Primary Care Policy references and guidelines. Therefore, the $\mathrm{CR}$ aims to increase access to health services to the population in street situation.

Drawn from the discourse of the CRT professionals, the emphases were on the aspects related to the resistance 
showed by Health Care Units (HCU) professionals in providing assistance and receiving the PSS, which was similar to the results of a study conducted in the countryside of the state of São Paulo: the authors observed that PHC professionals collectively raised questions that thwart the effective services provided to the PSS, practically excluding this possibility ${ }^{(13)}$.

As an organizational barrier, the current format of health services was pointed out. This a factual situation despite the city having a normative ruling in which the PSS may register in the HCU of his/her own choice, without the need to provide a fixed address or even a photo ID, since he/she is entitled to use just his/her social name. This result shows that access to the health system is an example where the legality of the proposal does not guarantee its implementation ${ }^{(14-15)}$.

Another limitation to $\mathrm{HCU}$ access is the failure of HCU professionals to acknowledge that the PSS has rights. The ideological and political conception of the Brazilian Sanitary Reform movement claimed that health was not an exclusively biological issue under the responsibility of the health services, but rather a social and political issue that must be addressed in the public arena: in other words, health is not seen as a right of citizenship ${ }^{(16)}$.

This aspect is the key point for the effectiveness of access, because both the professional and the user must be considered as part of the Unified Health System (SUS). In order to achieve social justice, it is necessary to have equality in the organization of health services ${ }^{(17)}$.

Although the SUS, as public policy, had been formulated under the perspective of universal access, social justice, and equality regarding the health care needs of the population, the equality concept should stand out "even if it has not be mentioned by the health legislation, for it is considered one of the elements of justice" (17).

However, there is still a limited understanding about the concept of equality and the initial resistance towards its implementation as a criterion for the elaboration of public guidelines ${ }^{(18)}$. The creation of public policies aimed at population in street situations is somewhat recent and, in the hard reality that the major Brazilian cities face, the PSS in general does not have access to the SUS ${ }^{(3)}$. Within the context of reducing health access inequalities, the study suggested that the SUS could promote equality from the point of view of ethics and justice, without compromising its universal and egalitarian aspects ${ }^{(18)}$.

It is important to strengthen the work of the CRTs, because these are tools capable of drawing attention to related public health and policies, through interventions that allow adjustments in the environment in which the PSS belongs.

Analyzing the PHC structure in the city, the respondents affirmed that the HCU with Family Health Care Strategy (FHCS), when compared to traditional HCU, received them better. In a study on the presence and extension of the PHC attributes in the city of Curitiba, which compared traditional HCS with FHCS HCU, the results showed that the FHCS had a higher presence and better extension of attributes than the PHC. However, accessibility was the attribute with a lower mean score, despite better results in the units with $\mathrm{FHCS}^{(19)}$. The accessibility attribute showed a lower score in a study conducted in Canada as well ${ }^{(20)}$. These results indicate that users' access to health care still faces some barriers to be overcome.

Among the issues raised about the $\mathrm{CR}$ work, several professionals mentioned advances and challenges in this area, emphasizing the importance of intersectoral work as a necessary condition for dealing with PSS' complex demands.

Intersectoral action is defined as the alignment of intervention strategy and resources among players from two or more sectors at the public level, in order to reach additional objectives that are relevant to and valued by all parties. Health is a product of daily life and, therefore, it goes beyond the exclusive boundaries of health sector practice ${ }^{(21)}$.

The ideological knowledge, the needs of PSS, having as reference the concepts of needs under the collective health perspectives, and based on the typology of needs ${ }^{(10)}$, as well as the comprehensiveness of the discourses from CRT professionals in this category, evidenced acknowledgment in the area of natural needs - in other words, related to preservation and perpetuation of life.

The abusive use of alcohol and other drugs by the PSS was reported by several professionals, and it was confirmed by CR users.

Living on the streets increases the risk of substance abuse. Such behavior is common among this population, and it was addressed as a way of mitigating the perception on breakdowns and losses suffered, and as a means for establishing closer ties with other PSS ${ }^{(3)}$.

While serving as a health service network reference for the population in street situations, the $\mathrm{CR}$ is also involved in issues related to infectious diseases - such as STDs/HIV/ AIDS and tuberculosis - as fully explained in conversations with CRT professionals.

The prevalence of HIV among populations in situations of risk within hosting institutions in São Paulo was 4.9\% (e.g., 17.4\% were seropositive for syphilis), and $55.4 \%$ had access to preventive actions ${ }^{(22)}$. As the CRTs provide care to this group, questions related to sex life and exposure to STDs/AIDS, including diagnosis and treatment of theses illnesses, must be addressed by professionals ${ }^{(3)}$.

The treatment of HIV/AIDS infection is protected by Law number 9.313/96, which regulates universal access to antiretroviral therapy (ART). In order to be eligible for these treatments, the first request from the HCU is registration: the user must have, in addition to a referral for treatment, a photo ID issued by the public agency ${ }^{(23)}$.

Under this adversarial context, CRT professionals face difficulties with follow-ups and adherence to the treatment. Users without IDs cannot obtain ART dispensation due to the criteria already mentioned.

Drawing on the typology of needs proposed by Heller ${ }^{(10)}$, the basic needs were evidenced in the discourses of CR users through their desire, referred by some (U 2 and $\mathrm{U} 5$ ), to return to work after the treatment period for alcohol and drug abuse carried out in the CAPS. Family conflicts were also mentioned as motivating factors for "staying, living, and being on the street" (U 5, U 6). 
Similar to natural needs, basic needs are socially determined $^{(10)}$. A study conducted with women in street situations in São Paulo revealed that the most common forms of violence were amongst themselves on the streets - for having debts with drug dealers, fighting for space, and petty theft - as what motivated them most ${ }^{(24)}$.

According to the typology of needs ${ }^{(10)}$, only one dimensional category in the discourse of CR professionals was observed. On the other hand, it was possible to identify two categories in the discourse of the CR users.

The result suggests that the professional point of view is a "biologicizing" view of care, even though it had the conception that the way people live on the street determines their health status, and that the population in street situations see their needs differently from what a professional might see.

As for tool knowledge, the multidisciplinary teamwork was considered to be the decisive factor for the $\mathrm{CR}$ working process. It represents the potential for resolute intervention on health care, when the aim is to promote integration among professionals and with users ${ }^{(25)}$. According to other studies, the presence of a multidisciplinary team serve as a facilitating element for the care of PSS ${ }^{(24,26-27)}$.

From this perspective, the need for investment in specialized professionals with training in Mental Health and Collective Health, to join the teams working in the $\mathrm{CRs}^{(26)}$, and the need for implementing practices that cause an impact on the processes for determining undesired health realities in our society, were pointed out ${ }^{(28)}$.

One of the practices used to meet the demands of PSS that took into consideration the specificities of working in the Street Outreach Office was the construction of relationships between professionals and users, a practice considered essential and necessary by the respondents. The emphasis on the relationship with health care practices has been acknowledged by several studies on population in street situations ${ }^{(24,26-27)}$. In this study, the focus was on building relationships and trust-based relations between CRT professionals and users, which would enable meeting the users' needs and their inclusion in the HCU.

However, training and maintaining the relationship have been reported as demanding and tenuous, and these factors remain a challenge for the CRTs. The complex nature of building relationships is related to the social invisibility characteristic of this group, making the PSS more reluctant to participate, and thus enhancing the fragile nature that involves this kind of approach. Several aspects have an influence on the relationship between the subjects involved in the CR, such as experience, knowledge, and access to available resources. The relationship, by itself, leads to brief responses, and not to a qualitative change in people's lives ${ }^{(29)}$.
Because the team is itinerant, the availability of portable electronic devices, such as tablets or notebooks, was viewed as a troublesome element for recording possible activities to be included in the records, according to respondent confirmation (P 04), followed by poor HCU infrastructure, which lacks rooms and computers.

Monitoring practices as well as evaluation of the actions carried out by the team that subsidizes health planning are directly related to the record-keeping information about the work. In the CRTs, such practices are associated with the organization of the working process, based on diagnosis of the territory, PSS' needs, and identification of problems in the teams' everyday lives.

For a typical work week, the respondents reported using a weekly activities calendar, based on the implemented planning and the time for approaching the PSS in loco in different working shifts.

Finally, the practices presented by the CR professionals correspond to the findings of the authors ${ }^{(30)}$, which emphasize the pursuit of a form of care that covers the principles of universality, equality, and quality, because there is no single health care format possible.

\section{CONCLUSION}

This study has enabled the identification of tool and ideological knowledge that make up the working process of the Street Outreach Office's professional teams.

According to the adopted framework, the centrality of the discourses was in the working process, supported by ideological knowledge. The structural dimension of the objective reality of the population in a street situation was visible in the social determination of situating the process on the street, to the extent that it corresponded with the predominant demand expressed by the respondents' discourses (CR professionals and users). Consequently, in the working process, the ideological knowledge stood out more than the CR organization itself as a care scenario, although this multi-professional team and the itinerant working format are still a recent concept.

The PSS cannot count on the PHC as his/her entrance door to the system, whether due to difficulties accessing it, as evidenced by the aspects related to the resistance of HCU professionals in assisting the PSS, or due to issues related to organizational barriers and the unavailability of ART mediations.

As these daily work contradictions are unveiled, the limitations to be overcome at the CRT working level are noticed. In order to move forward towards comprehensive care, it is up to the city government and workers to take the responsibility for reorganizing the health care model through the implementation of the PHC's guiding principles.

\section{RESUMO}

Objetivo: Identificar os saberes ideológicos e instrumentais que subsidiam o processo de trabalho do Consultório na Rua. Método: Pesquisa qualitativa e exploratória. A coleta de dados foi realizada junto a 20 profissionais e seis usuários do Consultório na Rua de um município do sul do Brasil, por meio de entrevistas com roteiros semiestruturados distintos para cada categoria de participantes. 
As classes resultantes foram analisadas à luz dos saberes ideológicos e instrumentais presentes no processo de trabalho. Resultados: Dos discursos dos participantes emergiram os saberes ideológicos: políticas públicas e necessidades da pessoa em situação de rua e os saberes instrumentais: dispositivos e instrumentos no cuidado à pessoa em situação de rua e agenda semanal. Conclusão: Constatou-se a centralidade dos discursos no processo de trabalho, sustentado pelos saberes ideológicos. A dimensão estrutural da realidade objetiva da população em situação de rua foi perceptível na determinação social do situar-se na rua. Ao descortinar contradições no cotidiano, apontam-se limites a serem superados no âmbito do processo de trabalho.

\section{DESCRITORES}

Pessoas em Situação de Rua; Atenção Primária à Saúde; Equipes de Assistência ao Paciente; Pessoal de Saúde; Pesquisa Qualitativa.

\section{RESUMEN}

Objetivo: Identificar los saberes ideológicos e instrumentales que subsidian el proceso laboral en el Consultorio en la Calle. Método: Investigación cualitativa y exploratoria. La recolección de datos fue llevada a cabo con 20 profesionales y seis usuarios del Consultorio de la Calle de un municipio del sur de Brasil, mediante entrevistas con guiones semiestructurados distintos para cada categoría de participantes. Las clases resultantes fueron analizadas a la luz de los saberes ideológicos e instrumentales presentes en el proceso laboral. Resultados: Desde los discursos de los participantes emergieron los saberes ideológicos: políticas públicas y necesidades de la persona en situación de calle y los saberes instrumentales: dispositivos e instrumentos en el cuidado a la persona en situación de calle y agenda semanal. Conclusión: Se constató la centralidad de los discursos en el proceso laboral, sostenido por los saberes ideológicos. La dimensión estructural de la realidad objetiva de la población en situación de calle fue perceptible en la determinación social de ubicarse en la calle. Al desvelar contradicciones en el cotidiano, se apuntan los límites que superar en el marco del proceso laboral.

\section{DESCRIPTORES}

Personas sin Hogar; Atención Primaria de Salud; Grupo de Atención al Paciente; Personal de Salud; Investigación Cualitativa.

\section{REFERENCES}

1. Brasil. Ministério do Desenvolvimento Social e Combate à Fome. Pesquisa Nacional sobre a População em Situação de Rua: sumário executivo [Internet]. Brasília; 2008 [citado 2016 jan. 23]. Disponível em: http://www.direito.mppr.mp.br/arquivos/File/Curitiba_pesquisa_ sobre_moradores_em_situacao_de_rua.pdf

2. Raoult D. Infection in homeless people. Lancet Infect Dis [Internet]. 2012 [cited 2016 Jan 21];12(11):822-3. Available from: http://www. thelancet.com/journals/laninf/article/PIIS1473-3099(12)70186-X/fulltext

3. Lopes LE. Caderno de atividades: curso atenção integral à saúde de pessoas em situação de rua com ênfase nas equipes de Consultórios na Rua. Rio de Janeiro: EAD/ESP; 2014.

4. Brasil. Decreto n. 7.053, de 23 de dezembro de 2009. Institui a Política Nacional para a População em Situação de Rua e seu Comitê Intersetorial de Acompanhamento e Monitoramento, e dá outras providências [Internet]. Brasília; 2009 [citado 2016 jan. 21]. Disponível em: http://www.planalto.gov.br/ccivil_03/_Ato2007-2010/2009/Decreto/D7053.htm

5. Souza D. Especificidades do atendimento à população em situação de rua. In: Brasil. Ministério da Saúde; Secretaria de Atenção à Saúde, Departamento de Atenção Básica. Manual sobre o cuidado à saúde junto à população em situação de rua. Brasília: MS; 2012 . p. 51-4.

6. Egry EY. Necessidades em saúde como objeto da TIPESC. In: Garcia TR, Egry EY, organizadoras. Integralidade da atenção no SUS e sistematização da assistência de enfermagem. Porto Alegre: Artmed; 2010. p. 70-7.

7. Tong A, Sainsbury P, Craig J. Consolidated criteria for reporting qualitative research (COREQ): a 32-item checklist for interviews and focus groups. Int J Qual Health Care [Internet]. 2007 [cited 2016 Jan 22];19(6):349-57. Available from: http://www.ncbi.nlm.nih.gov/ pubmed/17872937

8. Nascimento ARA, Menandro PRM. Análise lexical e análise de conteúdo: uma proposta de utilização conjugada. Estudos Pesq Psicol [Internet]. 2006 [citado 2016 jan. 22];6(2):72-88. Disponível em: http://www.revispsi.uerj.br/v6n2/artigos/pdf/v6n2a07.pdf

9. Lahlou S. Text mining methods: an answer to Chartier and Meunier. Pap Soc Represent [Internet]. 2012 [cited 2015 Dec 20];20:38.1-39.7. Available from: http://www.psych.Ise.ac.uk/psr/PSR2011/20_39.pdf

10. Heller A. Teoría de las necessidades en Marx. 2. ed. Barcelona: Península; 1986.

11. Chaves MMN, Medeiros ARP, Larocca LM, Peres AM. Saberes instrumentais e ideológicos no processo de trabalho de enfermeiros na vigilância epidemiológica hospitalar. Ciênc Cuid Saúde [Internet]. 2015 [citado 2015 ago. 10];14(2):1091-6. Disponível em: http:// periodicos.uem.br/ojs/index.php/CiencCuidSaude/article/view/28141/pdf_355

12. Starfield B. Atenção primária: equilíbrio entre necessidades de saúde, serviços e tecnologia. Brasília: UNESCO/Ministério da Saúde; 2002.

13. Borysow IC, Furtado JP. Access, equity and social cohesion: evaluation of intersectoral strategies for people experiencing homelessness. Rev Esc Enferm USP [Internet]. 2014 [cited 2016 Jan 23];48(6):1069-76. Available from: http://www.scielo.br/pdf/reeusp/v48n6/00806234-reeusp-48-06-1069.pdf

14. Assis MMA, Jesus WLA. Acesso aos serviços de saúde: abordagens, conceitos, políticas e modelo de análise. Ciênc Saúde Coletiva [Internet]. 2012 [citado 2015 ago. 23];17(11):2865-75. Disponível em: http://www.scielo.br/pdf/csc/v17n11/v17n11a02.pdf

15. Rehem TCMSB, Egry EY, Ciosak SI. Internações sensíveis à Atenção Primária: uso de ferramenta decodificadora para estudo das percepções dos profissionais da saúde, São Paulo, Brasil. Indagatio Didactica [Internet]. 2013 [citado 2015 jul. 26];5(2). Disponível em: http://revistas. ua.pt/index.php/ID/article/view/2448/2319

16. Paim J, Travassos C, Almeida C, Bahia L, Macinko J.The Brazilian Health System: history, advances, and challenges. Lancet [Internet]. 2011 [cited 2015 June 15]; 377(9779):1778-97. Available from: http://www.thelancet.com/pdfs/journals/lancet/PIIS0140-6736(11)60054-8.pdf 
17. Santos L, Andrade LOM. Acesso às ações e aos serviços de saúde: uma visão polissêmica. Ciênc Saúde Coletiva [Internet]. 2012 [citado 2015 abr. 04];17(11):2876-8. Disponível em: http://www.scielo.br/pdf/csc/v17n11/v17n111a03.pdf

18. Paim JS. Equidade e reforma em sistemas de serviços de saúde: o caso do SUS. Saúde Soc. 2006;15(2):34-46.

19. Chomatas E,Vigo A, Marty I, Hauser L, Harzheim E. Avaliação da presença e extensão dos atributos da atenção primária em Curitiba. Rev Bras Med Família Comunidade. 2013;8(29):294-303.

20. Haggerty JL, Pineault R, Beaulieu MD, Brunelle Y, Gauthier J, Goulet F, et al. Practice features associated with patient-reported accessibility, continuity and coordination of primary health care. Ann Fam Med [Internet]. 2008 [cited 2015 Feb 27];6(2):116-23. Available from: http:// www.ncbi.nlm.nih.gov/pmc/articles/PMC2267415/

21. Potvin L. Intersectoral action for health: more research is needed! [editorial]. Int J Public Health. 2012;57(1):5-6.

22. Grangeiro A, Holcman MM, Onaga ET, Alencar HDR, Placco ALN, Teixeira PR. Prevalência e vulnerabilidade à infecção pelo HIV de moradores de rua em São Paulo, SP. Rev Saúde Pública. 2012;46(4):674-84.

23. Brasil. Ministério da Saúde. Lei n. 9.313, de 13 de novembro de 1996. Dispõe sobre a distribuição gratuita de medicamentos aos portadores do HIV e doentes de Aids [Internet]. Brasília; 1996 [citado 2015 ago. 22]. Disponível em: http://www.planalto.gov.br/ccivil_03/ leis/L9313.htm

24. Rosa AS, Brêtas ACP. Violence in the lives of homeless women in the city of São Paulo, Brazil. Interface (Botucatu) [Internet]. 2015 [cited 2015 Aug 22];19(53):275-85. Available from: http://www.scielo.br/pdf/icse/v19n53/en_1807-5762-icse-19-53-0275.pdf

25. Chaves MMN, Egry EY. Competência avaliativa do enfermeiro para o reconhecimento e enfrentamento das necessidades em saúde das famílias. Cogitare Enferm. 2013;18(4):729-35.

26. Silva FP, Frazão IS, Linhares FMP. Práticas de saúde das equipes dos Consultórios de Rua. Cad Saúde Pública. 2014;30(4):805-14.

27. Hauff AJ, Turner MS. Homeless health needs: shelter and health service provider perspective. J Community Health Nurs. 2014;31(2):103-17.

28. Chaves MMN, Larocca LM, Peres AM. Collective Health Nursing: the construction of critical thinking about the reality of health. Rev Esc Enferm USP [Internet]. 2011 [cited 2014 Sep 05];45(n.spe2):1701-4. Available from: http://www.scielo.br/pdf/reeusp/v45nspe2/en_11.pdf

29. Guedes RN, Fonseca RMGS, Egry EY. The evaluative limits and possibilities in the family health strategy for gender-based violence. Rev Esc Enferm USP [Internet]. 2013 Apr [cited 2014 Sep 01];47(2):304-11. Available from: http://www.scielo.br/pdf/reeusp/v47n2/en_05.pdf

30. Merhy EE, Malta DC, Santos FP. Desafios para os gestores do SUS, hoje: compreender os modelos de assistência à saúde no âmbito da reforma sanitária brasileira e a potência transformadora da gestão [Internet]. 2012 [citado em 2014 set. 10]. Disponível em: http://www. uff.br/saudecoletiva/professores/merhy/indexados-30.pdf 